\title{
After Fire Regeneration in a Mediterranean Serpentine Mountain
}

\author{
Noelia Hidalgo Triana ${ }^{1^{*}}$, Andrés V. Pérez Latorre ${ }^{2}$ \\ ${ }^{1}$ University of Malaga, nhidalgo@uma.es \\ ${ }^{2}$ University of Malaga, Spain, avperez@uma.es
}

\section{ABSTRACT}

The management of Mediterranean mountains need to know whether or not the flora is adapted to respond to fire and, if so, through what mechanisms. Serpentine outcrops constitute particular ecosystems in the Mediterranean Basin, and plants need to make an additional adaptive effort. The objective of this study is to know the response to fire of the main members of the group of serpentine plants, which habit the Spanish Mediterranean ultramafic mountain, to help in their management. For this purpose, monitoring plots were established on a burned ultramafic outcrop, which was affected by fire in August 2012. They were located in the Mediterranean south of the Iberian Peninsula, Andalusia region. The dominant vegetation of this serpentine ecosystem had been studied previously to fire; it was a shrubland composed of endemic serpentinophytes (small shrubs and perennial herbs) included in Digitali laciniatae-Halimietum atriplicifolii plant association (Cisto-Lavanduletea class) in an opened pine forest. The post-fire response of the plants was studied in the stablished burned plots by field works through permanent $200 \times 10 \mathrm{~m}$ transect methods, consisting on checking whether they were resprouters, seeders, both of them or if they showed no survival response. Additional information about fire related functional traits is provided for the studied taxa from other studies. Of the total of plants studied (23 taxa), $74 \%$ acted as resprouters, $30 \%$ as seeders, some of which also had the capacity to resprout (13\%), and only $9 \%$ of the plants did not show any survival strategy. The presence of a resprouting burl was not high (17\%), although serpentine small shrubs such as Bupleurum acutifolium and the generalist Teucrium haenseleri had this kind of organ. The herbaceous taxa Sanguisorba verrucosa, Galium boissieranum and Linum carratracense were seen to be resprouters and seeders. The serpentine obligated Ni-accumulator, Alyssum serpyllifolium subsp. malacitanum, did not show any survival strategy in the face of fire and therefore their populations need monitoring after fires. In the studied ecosystems no species had traits that would protect the aerial part of the plant against fire, although most of the species are capable of post-fire generation by below ground buds. Our results show that the ecosystem studied, composed of taxa with a high degree of endemism and some of them threatened, is predominantly adapted to survival after a fire, although their response capacity may be decreased by environmental factors.

Keywords: Post-fire Regeneration; Ecosystem Management; Functional Trait; Shrubland Serpentine Endemics; Mediterranean Ranges

\section{Introduction}

Knowing how species respond to fire regimes is essential for ecologically sustainable management (Driscoll et al. 2010) and conservation of ecosystems. The management of vegetation in the face of forest fires in Mediterranean-type ecosystems, where fires are recurrent, involves studying whether plants are adapted to respond to this disruption or not and, if they are, what regeneration mechanisms are used as adaptation (Cabezudo et al. 1995; Lloret 2004; Ojeda 2004; Pausas and Bradstock 2007).

Most studies in Mediterranean ecosystems that have been affected by fire focus on tree communities or tall Mediterranean shrubs (Souto and Monteiro 1987; Cabezudo et al. 1995; Lloret et al. 1999; Pausas et al. 2004; Pausas and Bradstock 2007; Paula et al. 2009; Paula et al. 2016). In the mountains of the Mediterranean Basin (Keeley 1986; Keeley et al. 2012), shrubs and sclerophyllous trees tend to be resprouters and hardly any cases of seeder shrubs have 
been detected; shrubs can be seeders and resprouters, while perennial grasses only have the capacity to resprout. In other Mediterranean regions, such as California, South Africa and Southwest Australia, the presence of facultative seeders is more common in shrubs and scrubs (Keeley 1986). The percentage of plants without any kind of response capacity in these ecosystems tends to be low (Cabezudo et al. 1995). However, both the difficulties of survival of seedlings associated with germination and the availability of water and/or nutrients in the soil must be taken into account as a determining factor in resprouting (López-Soria and Castell 1992; Riba 1997; Cruz et al. 2002), as must herbivory (Cabezudo et al. 1995). However, there are few studies dealing with the regeneration of scrub-type ecosystems (Ojeda et al. 1996; Pérez Latorre et al. 2007; Paula et al. 2009). Currently, the database "BROT: plant trait database for Mediterranean Basin species" already includes the character Resprouting Ability after Fire, which has been studied for a large number of Mediterranean taxa which are mainly tall shrubs and trees (Paula et al. 2009). However, there are no studies on post-fire regeneration of serpentine mountains in the Mediterranean Basin, despite the large number of endemic scrub taxa that these possess (Pérez Latorre et al. 2013b) and despite their high conservation value for uniqueness or degree of threat (Bañares et al. 2003; IUCN 2012), natural values that could be much affected by a fire. In addition, its peculiarities at a landscape-level could involve a different response to fire compared with other ecosystems: a more open plant structure and low density and coverage, with low diversity of species but with a high presence of endemic species in relation to surrounding regions (Barbour and Major 1977; Kruckeberg 2002) in pine forests.

There are a number of functional characters (fire survival features) that plants have developed as a result of, or as a response to, various disturbances, including fires, that have occurred since antiquity (Paula et al. 2009; Keeley et al. 2011; Paula et al. 2016). Among these characters is thick bark (Orshan 1986); buds that are covered by thick bark survive intense fires and might have been favoured by differential selection under such regimes (Burrows 2000, 2002). This is typical of cork-producing Quercus forests (Cabezudo et al. 1995) or large trees such as conifers (Keeley et al. 2011), which shed branches that have been damaged by fire in the lower parts of the plant. However, Mediterranean scrubs do not get rid of these branches and may have organs such as burl or serotinous fruiting bodies (Keeley et al. 2011), which could be functional characters related to the response to fire or other disturbance. Biological type is also a character related to fire response (Paula et al. 2009). Characters that can induce greater flammability (fire enhancing traits) are: small leaves and fine branches (which make bushes burn better, but they can also be explained as the only efficient canopy structure for a small-leaved plant in a drought-prone climate), the presence of volatile parts in the body of the plant (such as resins in Cistus ladanifer), scaly and loose bark that leads to the canopy of the plant or the litter around it to burn more easily (Pérez Latorre et al. 2007), or dense canopies with a high proportion of dead wood and the retention of dead leaves and branches in the body of the plant during its life cycle (its low moisture content increases flammability) (Zedler 1995; Keeley et al. 2011; Hidalgo-Triana 2016).

Since the regeneration capacity of serpentine shrub vegetation of the Mediterranean Basin has not been studied previously, the aim of this work is to ascertain the response to fire of the main constituents of southern Iberian serpentine mountain ranges (shrubland) through the study of post fire functional traits, in order to contribute to the management and conservation of such a valuable ultramafic ecosystem which is present around the world.

\section{Material and Methods}

\subsection{Study area}

The study area (Figure 1) is located in one of the largest outcrops of peridotite in the Western Mediterranean area, the Sierra Alpujata mountain range $\left(72 \mathrm{~km}^{2}\right)$, near the city of Malaga in the autonomous community of Andalusia (Baetic mountains), in the south of the Iberian Peninsula (Spain). The floristic and phytosociological composition of this Sierra was studied for our research group during the year 2011 and the results were published in Pérez Latorre et al. (2013a). In August 2012, a big deal of this studied mountain was affected by a serious fire.

After the fire of 2012, three adjacent plots of 200 x 200 m, affected by the fire, were established in Sierra Alpujata (Cerro Castillejos, municipality of Coin, geographic coordinates: 30S 343104 m E 4052408 m N, Figure 1), about 450 
m a.s.l. and of peridotite lithology (IGME 1978). The dominant vegetation, studied previously to the fire (Pérez Latorre et al. 2013a), was a serpentine shrubland, mostly composed of small shrubs and perennial herbs that are included in the phytosociological association of Digitali laciniatae-Halimietum atriplicifolii (Cisto-Lavanduletea class, Pérez Latorre et al. 2013a).

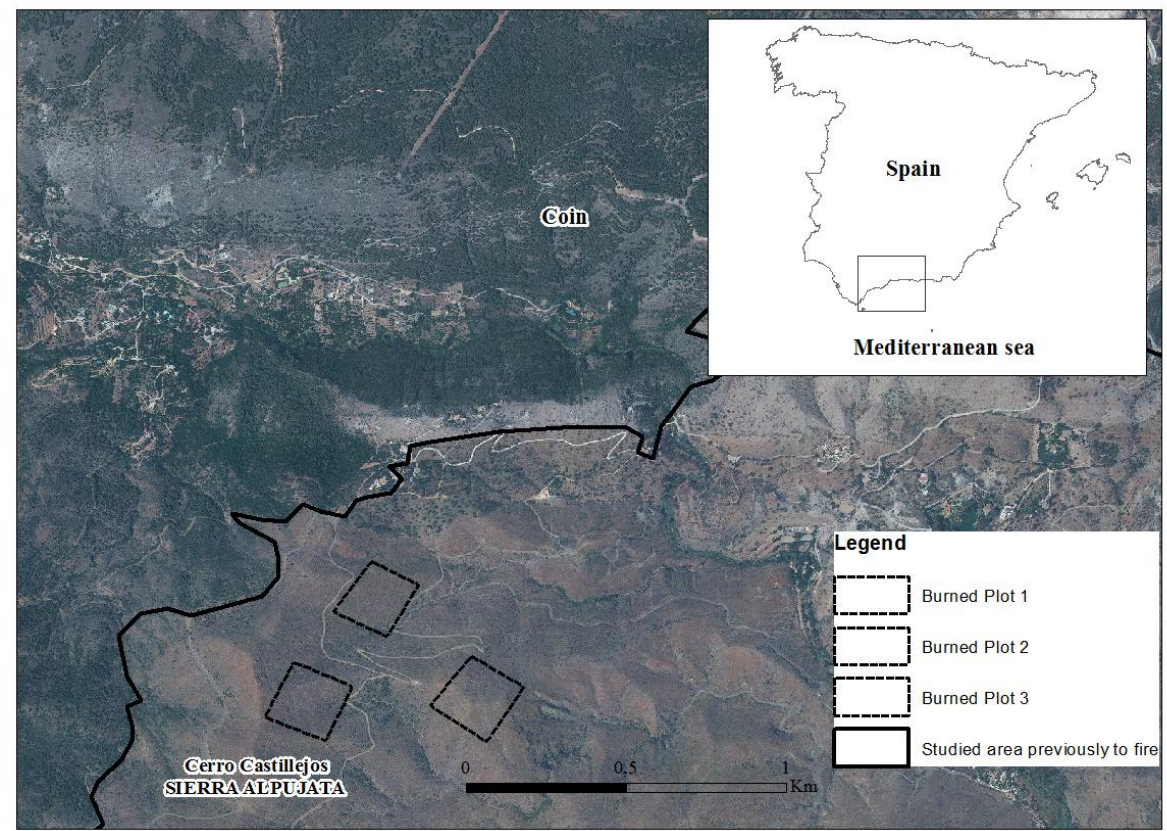

Figure 1; location of the study area in Sierra Alpujata (Cerro Castillejos) peridotite outcrop (southern Iberian Peninsula). Studied area previously to fire by Pérez Latorre et al., 2013a (solid line). Burned plots 1, 2 and 3 (dashed line box).

\subsection{Data collection}

Field surveys were conducted between October 2012 and February 2013 in the three selected plots.

The list of studied taxa (Table 1) was produced on the basis of their constant presence in the serpentine shrubland typical of the studied areas. Species nomenclature follows the "Vascular Flora of Eastern Andalusia" (Blanca et al. 2011) except Muñoz Garmendia et al. (2015) for Linaceae. In addition, we checked the degree of serpentinophily (serpentinophyte category) of the studied taxa (Pérez Latorre et al. 2013b).

During the sampling period, periodic field visits were made to the burned plots to study the post-fire response of the plants, with sufficient time between the samplings for the vegetation to show a possible response: first at recent fire, second after rain and finally at the growth period (six months after fire). A permanent $200 \times 10 \mathrm{~m}$ transect (minimum area) was marked in the three areas and measurements and collection of material were made during the studied period along the transects. In each sampling, we photographed and took samples to identify the taxon in question and the type of response after the fire. Possible response strategies were considered according to Orshan (1986), Lloret (2004), Pausas et al. (2004) and Hidalgo-Triana (2016) as follow: (1) resprouting of the plant from below ground epicormic buds, which are dormant at the base of the stems (SEB) (2) resprouting of the plant from surface epicormic buds (AEB); (3) resprouting of the plant by non-epicormic aerial buds (ANEB) (4) resprouting of plants through non-epicormic below ground buds in the roots (SNEB); and (5) regeneration of the population through seed germination. To study in detail the organ in which the resprouting originated, the sampled individuals (generally five samples per taxon) were extracted from the roots and transported to the laboratory to be studied more carefully. 


\begin{tabular}{|c|c|c|c|c|}
\hline Taxa & PS & BP & Family & Serpentine affinity \\
\hline $\begin{array}{l}\text { Alyssum serpyllifolium subsp. } \\
\text { malacitanum }\end{array}$ & $\mathrm{x}$ & $\cdot$ & Brassicaceae & $\mathrm{O}$ \\
\hline $\begin{array}{l}\text { Brachypodium retusum subsp. } \\
\text { retusum }\end{array}$ & $\mathrm{x}$ & $\mathrm{x}$ & Poaceae & Ns \\
\hline Bupleurum acutifolium & . & $\mathrm{x}$ & Apiacaee & $\mathrm{O}$ \\
\hline Carex distachya & . & $\mathrm{x}$ & Cyperaceae & Ns \\
\hline Cephalaria baetica & . & $\mathrm{x}$ & Dipsacaceae & $\mathrm{O}$ \\
\hline Cistus salviifolius & . & $\mathrm{x}$ & Cistaceae & Ns \\
\hline $\begin{array}{lll}\text { Digitalis obscura } & \text { subsp } \\
\text { laciniata } & & \\
\end{array}$ & $\mathrm{x}$ & . & Veronicaceae & M \\
\hline $\begin{array}{l}\text { Elaeoselinum asclepium subsp } \\
\text { millefolium }\end{array}$ & . & $\mathrm{x}$ & Apiaceae & M \\
\hline Erica scoparia subsp scoparia & . & $\mathrm{x}$ & Ericaceae & Ns \\
\hline $\begin{array}{lll}\text { Euphorbia flavicoma subsp. } \\
\text { flavicoma }\end{array}$ & . & $\mathrm{x}$ & Euphorbiaceae & Ns \\
\hline Fumana thymifolia & . & $\mathrm{x}$ & Cistaceae & Ns \\
\hline Galium boissieranum & . & $\mathrm{x}$ & Rubiaceae & $\mathrm{P}$ \\
\hline Genista hirsuta subsp. lanuginosa & $\mathrm{x}$ & $\mathrm{x}$ & Leguminosae & Sub \\
\hline $\begin{array}{lll}\text { Glandora } & \text { prostrata } & \text { subsp. } \\
\text { lusitanica } & & \\
\end{array}$ & . & $\mathrm{x}$ & Boraginaceae & Ns \\
\hline $\begin{array}{l}\text { Halimium atriplicifolium subsp. } \\
\text { atriplicifolium }\end{array}$ & $\mathrm{x}$ & $\mathrm{x}$ & Cistaceae & M \\
\hline Klasea baetica & . & $\mathrm{x}$ & Asteraceae & $\mathrm{O}$ \\
\hline Lavandula stoechas & $\mathrm{x}$ & $\mathrm{x}$ & Lamiaceae & Ns \\
\hline Linum carratracense & $\mathrm{x}$ & $\mathrm{x}$ & Linaceae & $\mathrm{O}$ \\
\hline Phlomis purpurea & $\mathrm{x}$ & $\mathrm{x}$ & Lamiaceae & Ns \\
\hline Sanguisorba verrucosa & . & $\mathrm{x}$ & Rosaceae & Ns \\
\hline Staehelina baetica & . & $\mathrm{x}$ & Asteraceae & $\mathrm{O}$ \\
\hline Teucrium haenseleri & . & $\mathrm{x}$ & Lamiaceae & Ns \\
\hline Ulex baeticus subsp. baeticus & $\mathrm{x}$ & $\mathrm{x}$ & Leguminosae & Ns \\
\hline
\end{tabular}

Table 1. Studied Taxa belonging to the serpentine community Digitali laciniatae-Halimietum atriplicifolii detected in the burned plots (BP). Detected presence of taxa during the previous studies (PS) to the fire (Pérez Latorre et al., 2013a) have been added. Families according to Blanca et al. (2011). Serpentine affinity by Pérez Latorre et al. (2013b): O Obligate; Ns Not serpentinophyte; P Preferential; M Magnesic; Sub Subserpentinophyte

\section{Results}

\subsection{Survival strategies}

Figure 2 summarizes the post-fire behaviour of the studied taxa, documented through photographs and Table 2 shows the apparition of the different regeneration strategies in the studied species during the different visits to the plot. 


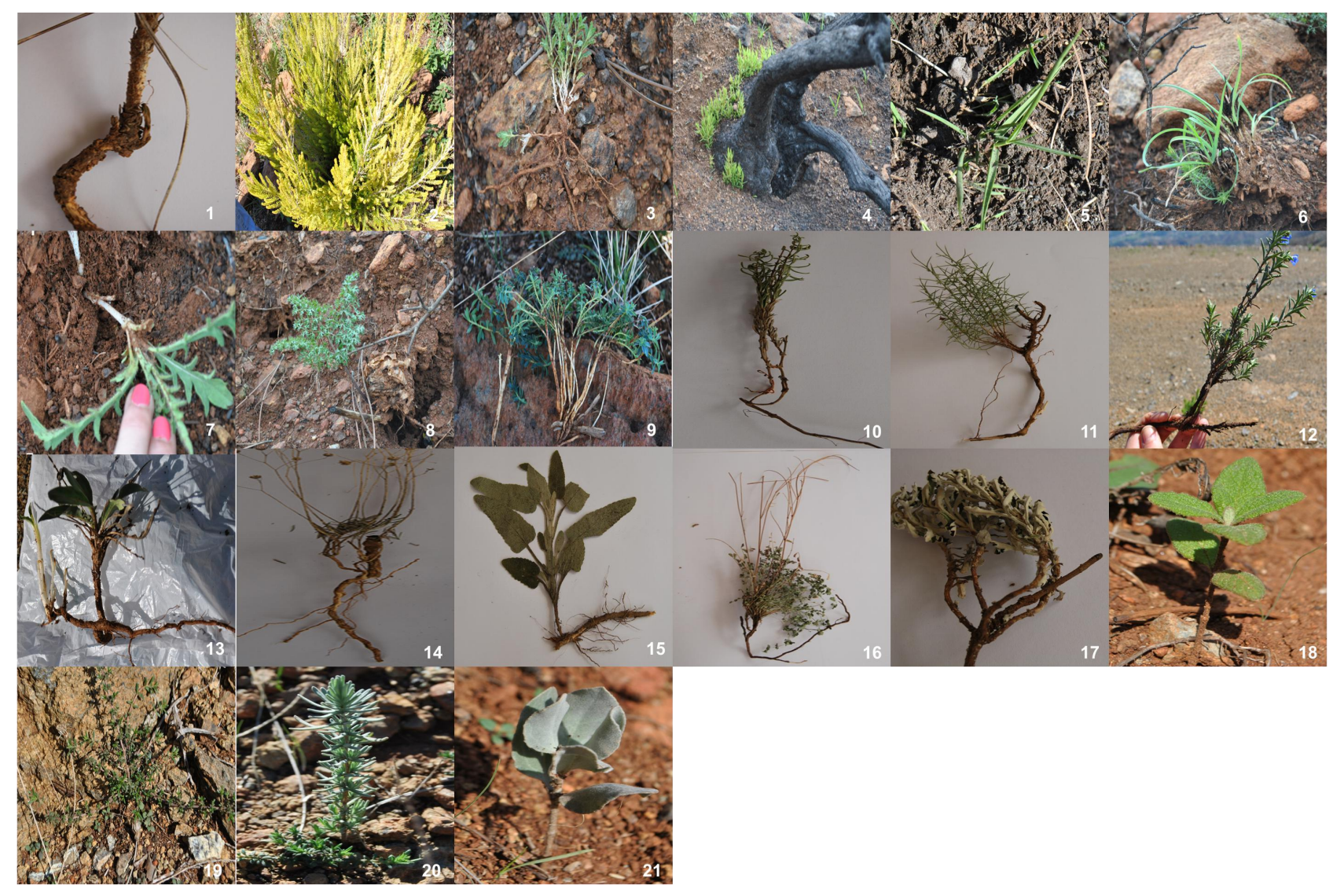

Figure 2; Post-fire regeneration strategies of the taxa studied: SEB resprouters (plants that regenerate through below ground epicormic buds) and SNEB resprouters (plants that regenerate through below ground non-epicormic buds) and post-fire vegetative regeneration. 1-4: SEB resprouters (burl) Bupleurum acutifolium (1), Erica scoparia subsp. scoparia (2), Teucrium haenseleri (3) and Ulex baeticus subsp. baeticus (4). 5-17, SNEB resprouters Brachypodium retusum subsp. retusum (5), Carex distachya (6), Cephalaria baetica (7), Elaeoselinum asclepium subsp. millefolium (8), Euphorbia flavicoma subsp. flavicoma (9), Galium boissieranum (10), Genista hirsuta subsp. lanuginosa (11), Glandora prostrata subsp. lusitanica (12), Klasea baetica (13), Linum carratracense (14), Phlomis purpurea (15), Sanguisorba verrucosa (16) and Staehelina baetica (17). 18- 21, germination of Cistus salviifolius (18), Fumana thymifolia (19) Lavandula stoechas, (20) and Halimium atriplicifolium subsp. atriplicifolium (21).

\begin{tabular}{|c|c|c|c|c|}
\hline Taxa & at recent fire & after rain & $\begin{array}{l}\text { at the growth } \\
\text { period }\end{array}$ & post-fire behaviour \\
\hline $\begin{array}{l}\text { Alyssum serpyllifolium subsp. } \\
\text { malacitanum }\end{array}$ & . & . & & Plant killed \\
\hline $\begin{array}{ll}\text { Brachypodium } & \text { retusum } \\
\text { subsp. retusum } & \\
\end{array}$ & . & . & + & SNEB resprouter \\
\hline Bupleurum acutifolium & . & . & + & SEB resprouter \\
\hline Carex distachya & . & + & + & SNEB resprouter \\
\hline Cephalaria baetica & & + & + & SNEB resprouter \\
\hline Cistus salviifolius & . & . & + & Seeder \\
\hline $\begin{array}{lll}\text { Digitalis obscura } & \text { subsp } \\
\text { laciniata } & & \\
\end{array}$ & . & . & . & Plant killed \\
\hline Elaeoselinum & . & + & + & SNEB resprouter \\
\hline
\end{tabular}




\begin{tabular}{|c|c|c|c|c|}
\hline subsp. millefolium & & & & \\
\hline Erica scoparia subsp scoparia & . & . & + & SEB resprouter \\
\hline $\begin{array}{l}\text { Euphorbia flavicoma subsp. } \\
\text { flavicoma }\end{array}$ & . & + & + & SNEB resprouter \\
\hline Fumana thymifolia & . & . & + & Seeder \\
\hline Galium boissieranum & . & + & + & SNEB resprouter/seeder \\
\hline $\begin{array}{l}\text { Genista hirsuta } \quad \text { subsp. } \\
\text { lanuginosa }\end{array}$ & . & . & + & SNEB resprouter \\
\hline $\begin{array}{l}\text { Glandora prostrata } \quad \text { subsp. } \\
\text { lusitanica }\end{array}$ & . & . & + & SNEB resprouter \\
\hline $\begin{array}{l}\text { Halimium atriplicifolium subsp. } \\
\text { atriplicifolium }\end{array}$ & + & . & + & Seeder \\
\hline Klasea baetica & . & + & + & SNEB resprouter \\
\hline Lavandula stoechas & . & . & + & Seeder \\
\hline Linum carratracense & . & . & + & SNEB resprouter/seeder \\
\hline Phlomis purpurea & . & + & + & SNEB resprouter \\
\hline Sanguisorba verrucosa & . & + & + & SNEB resprouter/seeder \\
\hline Staehelina baetica & . & . & + & SNEB resprouter \\
\hline Teucrium haenseleri & . & + & + & SEB resprouter \\
\hline Ulex baeticus subsp. baeticus & + & + & + & SEB resprouter \\
\hline
\end{tabular}

Table 2. Detected presence of strategies of regeneration after fire in the plants of the studied plots during the considered periods of sampling. Detected presence is marked with a + . Post fire behaviour or response strategies have been added according to Orshan (1986), Lloret (2004), Pausas et al. (2004) and Hidalgo-Triana (2016): SNEB: plants that resprouted through subterranean non-epicormic buds; SEB: plants that resprouted through subterranean epicormic bud; Seeder: plants that can be considered as germinators. Plant killed: plants that did not show the previous strategies

Of the total number of taxa studied in this work (23 taxa; Table 1) belonging to the Digitali laciniatae-Halimietum atriplicifolii association, approximately the 92\% had fire-survival strategies: 17 taxa (74\% of the plants) had the capacity to act as resprouters after fire (SNEB and SEB resprouters, Table 2 and Figure 3a), 7 plants (30\%) acted as seeders (Table 2 and Figure 3a), surviving through the production of new seedlings from the germination of seeds, of which Galium boissieranum, Linum carratracense and Sanguisorba verrucosa showed the capacity of act as a resprouters and as seeders (13\%, Table 2). Of the 17 taxa that resprouted, 13 taxa (57\%) did so using below ground non-epicormic buds (SNEB; Figure 3b) and 4 taxa (17\%) by subterranean epicormic buds (SEB; Figure 3b, Table 2). Aerial buds (AEB and ANEB) were not presented in the studied ecosystem (Table 2). Only 2 taxa (9\%), plants whose presence was known by previous studies (Pérez Latorre et al., 2013 a), did not show any survival strategy (Figure 3a, Table 2). Such was the case of the taxa Alyssum serpyllifolium subsp. malacitanum (obligated serpentinophyte and $\mathrm{Ni}$ hyperaccumulator, according to Asensi et al. 2004, Table 1) and Digitalis obscura subsp. laciniata (magnesicolous plant, Table 1). None of these showed fire survival strategies in this study. Alyssum serpyllifolium subsp. malacitanum is a hemixyle plant with a stem without thick bark (Electronic Supplementary Material), nor modified subterranean organs and Digitalis obscura subsp. laciniata is a holoxyle plant with warty bark and with burl (Electronic Supplementary Material). 


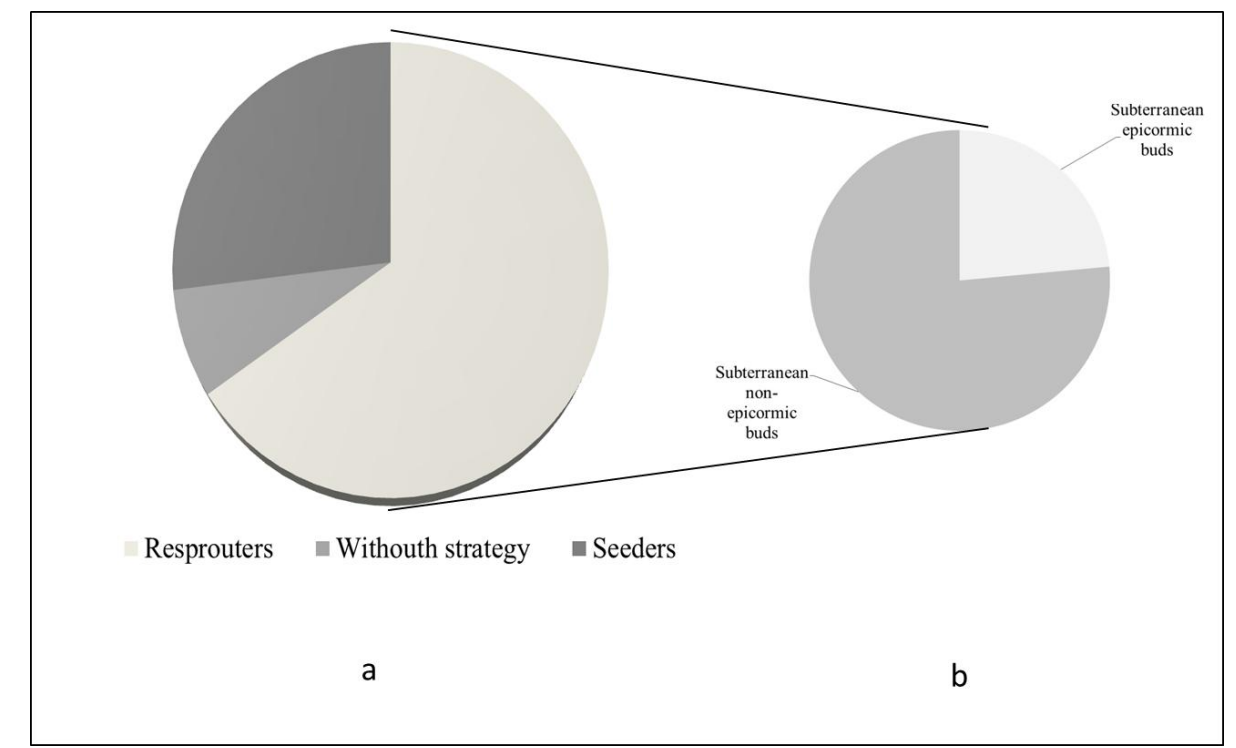

Figure 3; a. percentage of taxa of Digitali laciniatae-Halimietum atriplicifolii association showing resprouting, seed germination and with no survival strategy. b. among the resprouters, the percentage of plants that regenerate through subterranean epicormic buds (SEB) and those that do so with subterranean non- epicormic buds (SNEB).

Of note is the presence of burls in the phanerophytes Erica scoparia and Ulex baeticus (Electronic Supplementary Material) and in the small chamaephytes Bupleurum acutifolium (hemixyle, Electronic Supplementary Material) and in Teucrium haenseleri (SEB resprouters, Table 2). Regarding to the Table 2 and Table of Electronic Supplementary Material in the most of the plants that resprouted through subterranean non-epicormic buds (SNEB) the vegetative regeneration is due to the vegetative buds located on the roots in the case of the chamaephytes, and in rhizomes or bulbs in the case of hemicryptophytes and geophytes, respectively. They were fundamentally chamaephytes (small shrub, Table 2, Electronic Supplementary Material) with the exception of Carex distachya (herbaceous geophyte), Klasea baetica (herbaceous hemicryptophyte), Elaeoselinum asclepium subsp. millefolium (geophyte) and the herbaceous amphiphytes (chamaephyte and geophyte) Galium boissieranum and Euphorbia flavicoma subsp. flavicoma. Finally, all studied plants from the Cistaceae or Lamiaceae families (Table 1) presented post fire regeneration through the germination of new seedlings (Table 2). Two of seeder plants were the only ones with flammable surface substances (Electronic Supplementary Material). Among the germinators or seeders (Table 2), most were chamaephytes, with the exception of the amphiphyte Galium boissieranum (Electronic Supplementary Material).

With respect to the serpentine affinity (Table 1), among the plants that regenerate using below ground non-epicormic buds (SNEB, Table 2), 25\% were serpentinophytes of any kind such as: Cephalaria baetica, Galium boissieranum, Genista hirsuta subsp. lanuginosa, Klasea baetica, Linum carratracense and Staehelina baetica. The $8 \%$ that resprouted through epicormic below ground buds (SEB) were obligated endemic serpentinophytes such as: Bupleurum acutifolium (Table 1 and 2). The serpentinophytes Galium boissieranum and Linum carratracense (Table 1) were observed to act both as resprouters and germinators (Table 2). Sanguisorba verrucosa also showed this response.

Figure 4 compares the results obtained in this study with those obtained in other studies in other types of Iberian Mediterranean ecosystems such as cork oak forests (Pérez Latorre et al. 1996), heathlands (Pérez Latorre et al. 2007) and shrublands of Cistus ladanifer (Pérez Latorre and Cabezudo 2002). In the cork oak vegetation (Pérez Latorre et al. 1996), 90\% of the plants presented regeneration strategies. In other types of shrublands such as heathlands (Pérez Latorre et al. 2007) half of the plants were shown to be resprouters and the other half died, while in areas of Cistus ladanifer shrublands almost none presented vegetative regeneration and all died, although they were seen to be germinator plants (Pérez Latorre and Cabezudo 2002). 


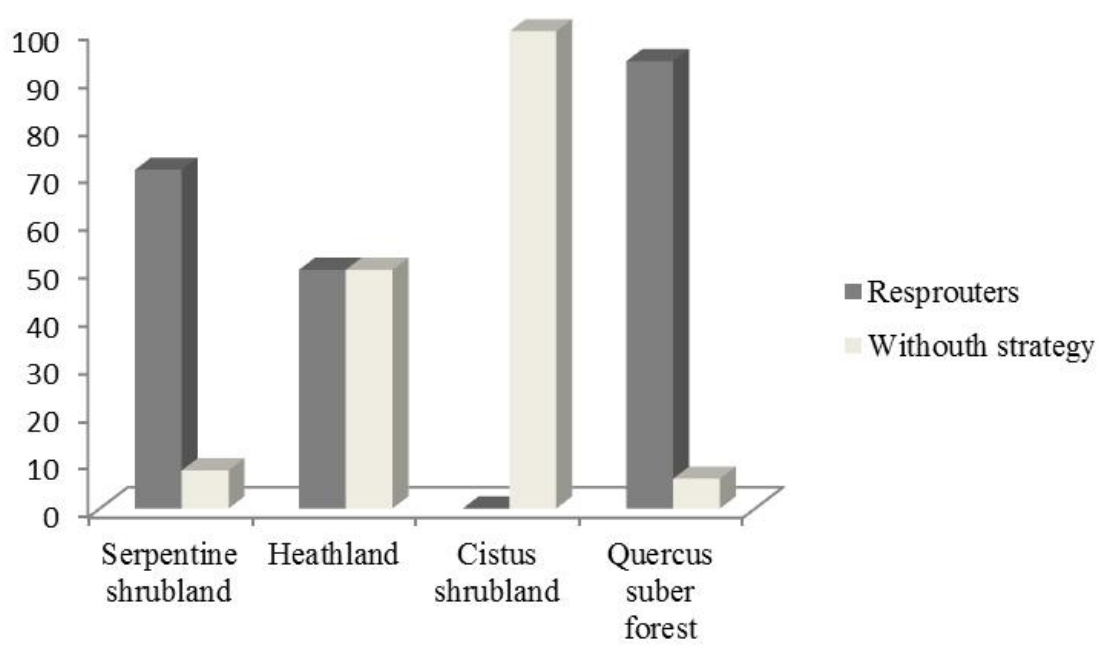

Figure 4; comparison of post fire survival strategies in different Iberian Mediterranean ecosystems. Cork oak forests (Pérez Latorre et al. 1996), heathlands (Pérez Latorre et al. 2007) and shrublands of Cistus ladanifer (Pérez Latorre and Cabezudo 2002).

\subsection{Other functional traits related to fire survival}

The functional characters related to the response after fire were studied in serpentine plants by Hidalgo-Triana (2016) in a similar serpentine mountain range (Sierra Bermeja): bark, thickness of twigs, and whether they are branch shedders or not, the type and size of the leaves, the type of root or subterranean organs, or the presence of organs with regenerative capacity (Orshan 1986; Keeley et al. 2011). They have been summarized in a table (Electronic Supplementary Material: Table). That Table indicates that most of the plants in the community studied were holoxyles with the presence of some hemixyle plants, predominantly of the small chamaephyte biological type, whose phenological strategy is to be branch shedders. As regard to the type of bark, plants without bark predominated or, if bark was present, its thickness never exceeded $2 \mathrm{~mm}$; the types of bark present were both smooth and fringed, the only warty barked taxon present being Digitalis obscura subsp. laciniata. As regards leaf size, the studied plants mainly had small malacophyllous leaves (between $0.25-2.25 \mathrm{~cm}^{2}$ ). Most taxa presented tap and thickened roots, as occurs in most serpentine ecosystems (Hidalgo-Triana et al., 2017) with the presence of burls or rhizomes in some cases, all of them candidates for resprouting after the fire. The presence of volatile substances was almost anecdotal, as only the seeders Lavandula stoechas and Cistus salviifolius (Hidalgo-Triana 2016) had them.

\section{Discussion}

\subsection{Survival strategies}

Most of the plants (92\% approximately) that live in Mediterranean serpentine shrub communities in the mountain ranges of south of the Iberian Peninsula have fire-survival strategies, with resprouting species being more predominant than germinators, as Keeley (1986) already mentioned for Mediterranean ecosystems in general. Species that are exclusively resprouters have certain advantages over germinators, since resprouting allows plants to live longer and to constantly renew their canopy increasing the possibility of reproduction. However, they are dependent on seasonal rainfall and the frequency of fire, because, if either is excessive, species can lose their resprouting capacity and therefore be eliminated (Bradstock 2008; Keeley et al. 2009). On the other hand, germinators have the disadvantage of there being a low probability of the seedlings establishing themselves (Keeley 1986) and the need for vegetative development and maturation before reproduction.

Among the existing strategies of resprouting, we should emphasize the low presence of resprouting by subterranean epicormic buds (SEB) in this studied vegetation, meaning low presence of organs related to resprouting at ground level, such as is burl. The presence of burl tends to be very common in phanerophytic plants (Lloret 2004), and the two phanerophytic plants existing in the ecosystem in question, Ulex baeticus subsp. baeticus and Erica scoparia subsp. scoparia, presented this organ. However, of particular note was the presence of burl in the serpentinophytes 
chamaephytes such as Bupleurum acutifolium (which is a hemixyle), and in Teucrium haenseleri. Also noteworthy is the resprouting ability of chamaephyte plants (nanochamaephytes), which do not have organs such as a lignotuber, but which have renewal buds in their roots that give them the ability to resprout after fire (SNEB resprouters). Studies in forests of the Mediterranean Basin (Lloret 2004) indicate that plants tend not to have the capacity for resprouting and germinating at the same time. This is reflected in our study, since only three taxa - Sanguisorba verrucosa and the serpentinophytes Galium boissieranum and Linum carratracense- showed this duality in their fire resistance strategy. Such a response, of course, provides taxa a higher capacity to respond to disturbances.

Only two taxa did not show any response strategies after fire; in the case of the Ni hyper-accumulator serpentinophyte Alyssum serpyllifolium subsp. malacitanum because it is a hemixyle plant with a stem that does not have any protecting organs such as thick bark, nor modified subterranean organs, it is concluded that it dies after a fire, so that efforts should be made to monitor its populations, since this is a strict serpentine endemism. However, the taxon with a broader distribution (magnesicolous) Digitalis obscura subsp. laciniata but with a warty bark, more fire-resistant (Keeley et al. 2011), and a root with lignotuber type modifications did not show signs of reestablishment in our plots. This could be explained by the random typical distribution of this species in serpentine communities (Pérez Latorre et al. 2013 a, b) since in other studies such as that of Paula et al. (2009) in Digitalis obscura s. 1., the taxon showed a post-fire response, probably through a burl organ, as Hidalgo-Triana (2016) observed. So it is possible to say that the only plant killed by fire in the studied ecosystem is Alyssum serpyllifolium subsp. malacitanum.

Our results are consistent with those obtained by Cabezudo et al. (1995) in a Mediterranean cork oak forest, and with those of Ojeda et al. (1996) and Pérez Latorre et al. (2007) in physiognomically similar Mediterranean heathlands. In Cistus ladanifer shrublands (Pérez Latorre and Cabezudo 2002), the authors also found facultative seeders Erica sp., Genista sp., and Ulex sp., whereas in our study these genera only showed a vegetative resprouting capacity.

\subsection{Other functional traits related to fire survival}

Coinciding with other studies of the Mediterranean shrubland (Pérez Latorre and Cabezudo 2002), no species in the studied ecosystem had a resistant thick bark that would protect it against fire, although most of the species are capable of post-fire generation by means of below ground buds, suggesting that the plants invest in strategies of regeneration related with their underground organs at the expense of producing bark to protect them against fire. However, the ability to shed the dead branches would decrease the flammability of the chamaephytes themselves, as indicated by Keeley et al. (2011), although this claim is not applicable to the ecosystem as a whole, since the same branches on the ground would help to propagate fire. Indeed, low fertility soils select for traits such as small sclerophyllous leaves and provide well-drained substrates, both of which increase the likelihood of fires. In our view, plants with small leaves, which are mainly malacophyllous (Keeley et al. 2011), would be a character more related to adaptation to the Mediterranean climate than to any resistance of plants to fire (Hidalgo-Triana 2016).

Although it was observed that most of the studied plants (included the endemic serpentinophytes) have the capacity to respond to a disturbance as drastic as fire is, such responses may be conditioned by the water available in the soil at the time of the regeneration (López Soria and Castell 1992; Riba, 1997; Cruz et al. 2002), the size of the plant (Lloret and Lopez-Soria 1993), the recurrence or severity of the fire (Safford and Harrison 2004; Pausas et al. 2004), the existence of other disturbances such as grazing (Cabezudo et al. 1995), especially in the case of resprouters (Pausas and Keeley 2014), or post-fire management practices (Castro et al. 2013). Moreover any responses may require much time (Meira-Neto et al. 2011). Therefore, our results indicate that the studied ecosystem, which is composed of a large number of plants with a high degree of endemism and suited to serpentine ecosystems (serpentinophytes, Pérez Latorre et al. 2013b), is adapted to survive after a fire if the rest of the environmental conditions allow it, although the time needed for the ecosystem and associated environmental conditions to be re-established is high - according to Meira-Neto et al. (2011) as long as 20 years. Consequently, our management recommendation is that more investment should be allocated in fire prevention than in post-fire ecosystem management. 


\section{Conclusions}

We demonstrated that most southern Iberian serpentinophytes belonging to the widespread serpentine community Digitali laciniatae-Halimietum atriplicifolii are adapted to survive after a fire, mainly through vegetative resprouting. However, because there are some taxa that do not have this ability and since both vegetative resprouting and germination of new seedlings depend on environmental conditions and on management, extra precaution and arrangements must be taken to prevent fires. Further studies are necessary to test the post-fire survival ability of other serpentine ecosystems in the world, to ascertain whether this ability is common worldwide or not.

\section{References}

1. Asensi A, Rodríguez N, Díez-Garretas B, et al.Nickel hyperaccumulation of some subspecies of Alyssum serpyllifolium (Brassicaceae) from ultramafic soils of Iberian Peninsula. In: Boyd RS, Baker AJM and Proctor J. (eds.). Ultramafic rocks: their soils, vegetation and fauna, Proceedings of the IV International Conference on Serpentine, Ecology. Science Reviews, 2004; 263-265.DOI: http://dx.doi.org/10.1071/BT14245

2. Bañares A, Blanca G, Güemes J, et al. Atlas y Libro Rojo de la Flora Vascular Amenazada de España, Dirección General de Conservación de la Naturaleza y Sociedad, Madrid 2003.

3. Barbour MG, Major J. Terrestrial vegetation of California. In: O'Geen AT, Dahlgren RA, Sanchez-Mata D (eds.) Chapter three: California soils and examples of Ultramafic Vegetation, Wiley Interscience, New York 1977.

4. Blanca G, Cabezudo B, Cueto M, et al. (Eds), Flora Vascular de Andalucía Oriental (2ª edición corregida y aumentada), Consejería de Medio Ambiente, Junta de Andalucía, Sevilla. 2011; 1751.

5. Bradstock R. Effects of large fires on biodiversity in southeastern Australia: disaster or template for diversity? International Journal of Wildland Fire 2008; 17: 809-822.DOI: https://doi.org/10.1071/WF07153

6. Burrows GE.An anatomical study of epicormic bud strand structure in Eucalyptus cladocalyx (Myrtaceae). Aust J Bot 2000; 48: 233-245.DOI: 10.1071/BT98075

7. Burrows GE.Epicormic strand structure in Angophora, Eucalyptus and Lophostemon (Myrtaceae) - implications for fire resistance and recovery. New Phytologist 2002; 153: 111-131.DOI: 10.1046/j.0028-646X.2001.00299.x

8. Cabezudo B, Pérez Latorre AV, Nieto JM. Regeneración de un alcornocal incendiado en el Sur de España (Istán, Málaga). Acta Botanica Malacitana1995; 20: 143-151.

9. Castro J, Leverkus AB, Marañón-Jiménez S, et al. Efecto del manejo de la madera quemada sobre la restauración y regeneración post-incendio: implicaciones para la gestión y para el conjunto del ecosistema. In: Actas del $6^{\circ}$ Congreso Forestal Español, Sociedad Española de Ciencias Forestales, 6CFE 01-242,2013.

10. Cruz A, Pérez B, Quintana JR, et al. Resprouting in the Mediterranean-type shrub Erica australis affected by soil resource availability. Journal of Vegetation Science2002; 13: 641-650.DOI: 10.1111/j.1654-1103.2002.tb02092.x

11. Driscoll DonA, Lindenmayer DB, Bennett AF, et al.Fire management for biodiversity conservation: Key research questions and our capacity to answer them. Biological Conservation 2010; 143 (9): 1928-1939.DOI: https://doi.org/10.1016/j.biocon.2010.05.026

12. Hidalgo-Triana N. Tipos funcionales (fenomorfología y ecomorfología) de la flora y vegetación serpentinícola mediterránea en Andalucía y California. PhD thesis, University of Málaga, Spain. (In Spanish)2016

13. Hidalgo-Triana, N, Pérez Latorre, AV, et al. Plant functional traits and groups in a Californian serpentine chaparral2017Ecol Reshttps://doi.org/10.1007/s11284-017-1532-6

14. IGME Piles ME, González EC, Martín BA (1978) Coin (Hoja 1066). Magna 50. 2ª Serie, 1978.

15. IUCN (2012) Categorías y Criterios de la Lista Roja de la UICN: Versión 3.1. Segunda edición. Gland, Suiza y Cambridge, Reino Unido: UICN. vi + 34pp. Previously published as IUCN Red List Categories and Criteria: Version 3.1. Second edition. (Gland, Switzerland and Cambridge, UK). http://www.iucnredlist.org/ (Accessed on December 2015).

16. Keeley JE. Resilience of Mediterranean shrub communities to fire. In: Dell B, Hopkins AJM and Lamonts BB (eds.) Resilience in Mediterranean-type Ecosystems. Dr. W. Junk, Dordrecht, 1986; 95-112.

17. Keeley JE, Aplet GH, Christensen NL, et al.Ecological Foundations for Fire Management in North American Forest and Shrubland Ecosystems, USDA Forest Service, Pacific Northwest Research Station.,2009 .

18. Keeley JE, Pausas JG, Rundel PW, et al.Fire as an evolutionary pressure shaping plant traits. Trends in Plant Science 2011; 16(8): 406-411.

19. Keeley JE, Bond WJ, Bradstock RA, et al. Fire in Mediterranean Ecosystem: Ecology, Evolution and Management. Cambridge: Cambridge University Press,2012DOI: https://doi.org/10.1016/j.tplants.2011.04.002

20. Kruckeberg A (2002) Geology and plant life. University Press. Washington.

21. Lloret F, López-Soria L.Resprouting of Erica multiflora after experimental fire treatments. Journal of Vegetation Science 1993; 4: 367-374.DOI: 10.2307/3235595

22. Lloret F, Verdú M, Flores-Hernández N, et al. Fire and resprouting in Mediterranean ecosystems: insights from an external biogeographical region, the Mexican shrubland. American Journal of Botany 1999; 86:1655-1661.DOI: 


\section{$10.2307 / 2656663$}

23. Lloret F.Régimen de incendios y regeneración. In: Valladares, F. (ed.) Ecología del bosque mediterráneo en un mundo cambiante, Ministerio de Medio Ambiente, EGRAF, Madrid, 2004; 101-126.

24. López-Soria L, Castell C. Comparative genet survival after fire in woody Mediterranean species. Oecologia 1992; 91: 493-499.DOI: 10.1007/BF00650321

25. Meira-Neto JAA, Clemente A, Oliveira G, et al.Post-fire and post-quarry rehabilitation successions in Mediterranean-like ecosystems: Implications for ecological restoration. Ecological Engineering 2011; 37: 1132-1139.DOI: https://doi.org/10.1016/j.ecoleng.2011.02.008

26. Muñoz Garmendia F, Navarro Aranda C ,Quintanar Sánchez A (eds.) Flora Iberica 9. Real Jardín Botánico, CSIC. Madrid,2015 .

27. Ojeda F, Marañón T, Arroyo J. Postfire Regeneration of a Mediterranean Heathland in southern Spain. International Journal of Wildland Fire1996; 6(4): 191-198.DOI: 10.1071/WF9960191

28. Ojeda F. Respuesta de las plantas al fuego. In: Herrera CM (coord) El monte mediterráneo en Andalucía, Consejería de Medio Ambiente, Junta de Andalucía, Sevilla, 2004; 153-159.

29. Orshan G. Plant form as describing vegetation and expressing adaptation to environment. Annals of Botany 1986 ; 54: 7-37.

30. Paula S, Arianoutsou M, Kazanis D, et al. [dataset] BROT: Fire-related traits for plant species of the Mediterranean Basin. Ecology 2009; 90: (5), 1420.

31. Paula S, Naulin PI, Arce C, et al. Lignotubers in Mediterranean basin plants. Plant Ecology 2016; 217: 661-676.DOI: doi:10.1007/s11258-015-0538-9

32. Pausas JG, Bradstock RA, Keith DA, et al.Plant functional traits in relation to fire in crown-fire ecosystems. Ecology 2004; 85: 1085-1100.

33. Pausas JG, Bradstock, RA Fire persistence traits of plants along a productivity and disturbance gradient in Mediterranean shrublands of SE Australia. Global Ecology and Biogeography 2007; 16: 330-340.DOI: 10.1111/j.1466-8238.2006.00283.x

34. Pausas JG, Keeley JE. Evolutionary ecology of resprouting and seeding in fire-prone ecosystems. New Phytologist2014; 204: 55-65. DOI: 10.1111/nph.12921

35. Pérez Latorre AV, Cabezudo B, Navarro T, et al.Caracterización fenológica y ecomorfológica de alcornocales andaluces (Málaga, España). Anales del Jardín Botánico de Madrid 1996; 54: 554-560.DOI: http://editaefa.com/aefa/PDF/Perez_Latorre/Alcornocales_Andaluces.pdf

36. Pérez Latorre AV, Cabezudo B.Use of monocharacteristic growth forms and phenological phases to describe and differentiate plant communities in Mediterranean-type ecosystems. Plant Ecology 2002 ; 161: 231-249.DOI: doi.org/10.1023/A:1020327522487

37. Pérez Latorre AV, Gavira O, Cabezudo B. Ecomorphology and phenomorphology of Mediterranean heathlands (SW Iberian Peninsula). Phytocoenologia2007;37: 239-268.DOI: 10.1127/0340-269X/2007/0037-0239

38. Pérez Latorre AV, Hidalgo Triana N, Casimiro-Soriguer F, et al. Flora y vegetación serpentinícola Ibérica: Sierras de Alpujata y La Robla (Málaga, España).Lagascalia2013;33:43-74.DOI: http://institucional.us.es/revistas/lagascalia/33/art_4.pdf

39. Pérez Latorre AV, Hidalgo-Triana N, Cabezudo B. Composition, ecology and conservation of the south-Iberian serpentine flora in the context of the Mediterranean basin. Anales del Jardin Botanico de Madrid 2013; 70(1): 62-71.doi: http://dx.doi.org/10.3989/ajbm.2334

40. Riba M. Effects of cutting recurrence and rainfall pattern on resprouting vigour and growth of Erica arborea L. Journal of Vegetation Science 1997; 8: 401-404.DOI: 10.2307/3237330

41. Safford H, Harrison S.Fire effects on plant diversity in serpentine versus sandstone chaparral. Ecology2004; 85: 539-548.DOI: 10.1890/03-0039

42. Souto C, Monteiro A. Ecological fire influences on Q. suber forest ecosystems. Journal of Mediterranean Ecology 1987; 13(4): 69-77.DOI: http://agris.fao.org/agris-search

43. Zedler PH. Are some plants born to burn? Trends in Ecology \&amp; Evolution1995; 10 (10): 393-394.DOI: https://doi.org/10.1016/S0169-5347(00)89153-3 